\title{
ECONOMIC MICRO-SYSTEMS? NON-MARKET AND NOT-ONLY-FOR-PROFIT ECONOMIC ACTIVITIES IN ECO-COMMUNITIES ${ }^{1}$
}

\author{
JAN BLAŽEK
}

\begin{abstract}
Eco-communities are a potential model for the socio-technological transition to a post-carbon society. The debate over their economic sustainability has, however, been limited. This article aims to enhance the discussion by offering a conceptualization of the economic micro-system created in eco-communities. It uses the economic terms households and firms to discuss two ways in which the community economy is positioned and then goes on to explore the principles behind the non-market (non-monetary) activities of households and the not-only-for-profit activities of firms as the basis of the eco-community economy. It concludes by pointing out that both can operate in parallel, with eco-communities producing non-market capital that can be used to develop not-only-for-profit activities which support the economic sustainability of the projects.
\end{abstract}

Key words: eco-community; non-market economy; economic sustainability; not-only-for-profit economy; eco-social enterprise.

\section{Introduction}

An eco-community (ecological intentional community) is a settlement (or social structure) created intentionally by a group of people to fulfil collective environmentally conscious goals (Meijering, 2006), such as voluntary simplistic living, reducing the carbon footprint, providing food or being energy-sufficient. They may consist of a few cooperating families or members of a single-unit community settlement, or several hundreds of members in larger ecovillages and cohousings, which are the two most-cited types of eco-communities (see e.g. Meltzer, 2010 on comparisons of both types; see Christian, 2007; Dawson, 2010; Meijering, 2006 for more types).

\footnotetext{
${ }^{1}$ This article was written at Masaryk University as part of a project entitled „Aktuálne prístupy k štúdiu environmentálnych fenoménov II, [Current approaches to researching environmental phenomena II]", no. MUNI/A/1004/2015 with the support of a Specific University Research Grant, provided by the Czech Ministry of Education, Youth and Sports 2015.
} 
Several studies have proven that eco-communities can significantly reduce energy consumption (Cattaneo \& Gavaldà, 2010; Hawasly et al., 2010; Williams, 2008; Zhu et al., 2012), carbon gas emissions (Simon et al., 2004) and members' carbon footprints (Tinsley $\&$ George, 2006). Many case studies have been conducted into environmentally-friendly collective lifestyles (see e.g. Jones, 2011; Kirby, 2003; Litfin, 2014; Sanguinetti, 2014). There has been a great deal of discussion on the utopianism of eco-communities (Lockyer, 2007; Metcalf, 2012; Sargisson, 2007), in relation to land-use and urban planning (Boyer, 2014; Xue, 2014), sustainable building (Pickerill \& Maxey, 2012; Zhu et al., 2012) and food (Newman \& Nixon, 2014).

Eco-communities can also be understood as important socio-technical niches and incubator centres of the social economy at a local level (Boyer, 2014; see also Seyfang, 2010; Seyfang \& Smith, 2007). In conjunction with other economic alternatives, such as (eco-) social enterprises (Borgaza \& Defourny, 2001; Johanisova, Crabtree, \& Fraňková, 2013; Johanisová \& Fraňková, 2013), community-based initiatives (Celata \& Sanna, 2014) and transition town initiatives (Connors \& McDonald, 2011; Hopkins, 2010), they can play an important role in the transition towards a less energy demanding post-carbon society.

Eco-communities differ from these heterodox structures in that they provide the residency function for their members. However, it would be a mistake to limit our understanding of eco-communities only to housing. They are as important because they are grassroots housing alternatives that have a lower environmental impact (Chatterton, 2013; Pickerill \& Maxey, 2012) as because they develop and implement non-market solutions in consumption (Lietaert, 2010) and the non-market and 'not-only-for-profit' production of goods and services. In other words, the residential aspect of eco-community settlements enables them to develop different activities within the same (infra)structure, combining the characteristics of environments known in economic theory as households and firms. ${ }^{2}$

If we understand the household and firm environments in eco-communities as synergic, then we can consider them to be economic micro-systems. To support research on their economic sustainability, this article aims to provide a theoretical basis for discussing the non-market economic activities of subsistence, gift and exchange between residents (the household environment) and the non-market and the not-only-for-profit production of goods and services (the firm environment) activities that serve the (local) economy and enable market exchange which fosters financial sustainability.

This article is a contribution to recent discussions about heterodox economic structures and so will follow the approach adopted in Johanisova et al. (2013), where the authors discuss the position of social enterprises ${ }^{3}$ in the economic system. First, it will look at why

\footnotetext{
${ }^{2}$ Eco-communities are not the only structures that have the characteristics of both households (consumers) and firms (producers). Many commons-based or peer-to-peer projects (particularly Internet-based ones), open source programming or the DIY culture, among others, are based on the logic that the consumer is also a producer (the prosumer). See e.g. Benkler and Nissenbaum (2006).

${ }^{3}$ Social or eco-social enterprises can be seen as close allies of the eco-community movement in practice as well in heterodox economic thinking. Since they have similar goals and organization models, we may build upon the previous work of Johanisova et al. (2013). In fact, as we will explore in the following sections, some eco-communities can be considered to be specific eco-social enterprises.
} 
mainstream economics theory and the market mechanism cannot satisfactorily be used on their own and then we will explore the concepts of the non-market community household economy and the not-only-for-profit community firm economy.

\section{Research on the eco-community economy}

Little research has been conducted to reflect on eco-communities economically (see Wagner, 2012 for a research review on ecovillages). Thus far the research 1) has not developed a theoretical framework on the eco-community economy; 2) has not provided sufficient evidence about their financial or socio-economic sustainability; and 3) has not proposed accounting methods that would enable economic evaluations to be made that take account of the multi-perspective social, economic and environmental objectives and character of the collective economy.

Cattaneo and Gavaldà (2010) have conducted a comprehensive study in two Catalonian autonomous projects investigating the economic and organizational structure and evaluating time and energy consumption, arguing that "it is possible to live well within a low-intensity economy". Also, a survey comparing intentional and unintentional communities conducted by Mulder, Costanza, and Erickson (2006) provides interesting data on the contribution of built, human, social and natural capital to quality of life, proving that intentional communities can successfully balance different capitals, substitute social capital for built capital and provide a higher quality of life despite having significantly lower incomes. Other economic research has been limited to specific issues, such as the level of self-sufficiency (DePasqualin et al., 2008) or the livelihood strategies of members (Gálová, 2013).

The eco-community movement publishes information on their websites, in magazines (e.g. Communities: Life in Cooperative Culture) and books by eco-community scholars (Dawson, 2010; Dawson et al., 2010; H. Jackson, 1999; J. T. R. Jackson, 2000; Walker, 2005). These provide a holistic view of eco-community life, and in terms of economics they focus on promoting a socially and environmentally responsible ethical framework for the community economy and on presenting examples of organizational structures, economic activities or financing methods. Very often, however, the movement focuses on presenting the 'best examples' of the well-known, long-established larger eco-communities typically defined as ecovillages and cohousings (such as the Findhorn Foundation, Damanhur, EcoVillage Ithaca, Earthhaven ecovillage, etc.). These have very diverse economies and portfolios of activities which can be elaborated; however, they differ significantly from most of the smaller, less promoted eco-communities (e.g. Can Tonal or Comunitat Pujarnol in Catalonia; Tribodar or The Hive in Portugal, among others). In this article a combination of both the well-established big projects and the small but equally important eco-communities will be considered. ${ }^{4}$

The gap in the research may be the result of the eco-communities' primary eco-social (and also political and spiritual) focus and a failure to consider them as economic structures.

\footnotetext{
${ }^{4}$ The projects were identified in 2015 and 2016 as part of the author's PhD project entitled The economy of eco-social intentional communities: socioenvironmental strategies and the financial sustainability $(E C O S-I C)$. The information comes from personal visits and/or the project websites.
} 
If we take the economic aspect into account, the sustainability of eco-communities can be investigated, potentially providing new arguments in favour of the community life-style.

\section{Limits of the market economy: the household-firm dichotomy}

In mainstream economics, the economy is largely created as a result of the activities of two types of agents in the market—households (consumers) and firms (producers)—in addition to the actions of the public sector (governments) and the financial sector (banks). Together these sectors create the monetized economy. In most economics textbooks, for example Fuchs and Tuleja (2005) and Samuelson and Nordhaus (1992), the household-firm dichotomy is presented as the "two-sector" model of the economy. The role of households and firms is facilitated by the market mechanism.

Households are the consumers of goods and services and the owners of the factors of production (labour, land and capital), which they rent to firms who are the primary producers of goods and services. The price (of the services, goods and factors of production) is the necessary information the market needs to allocate resources. These principles of the market economy are built on the assumption that the household's goal is to maximize its utility, while the firm aims to maximize profits. ${ }^{5}$

It is worth mentioning that for legal, statistical and demographic purposes the terms household and firm have a different meaning from that used in economic theory. In a broader sense, the term household is usually used to refer to a situation in which one or more people share common dwellings or income. ${ }^{6}$ A firm is an institution (a for-profit enterprise, public enterprise or non-profit institution) that has one or more legal identities and produces goods and services. ${ }^{7}$

If we overlook its simplicity for the moment, we could attempt to apply the logic of the market mechanism to eco-community economies. In this case the individuals who form the eco-community can be understood as households (in the economic sense) when employed by a market firm or when they obtain goods or services from the market economy. When the individuals establish entities that produce goods or services for the market (including sales within the eco-community) or that create paid jobs, they can be seen as firms (in the economic sense).

Using market logic, the eco-communities do not differ much from other individuals or groups of people that economically perform as households whilst forming firms at the

\footnotetext{
${ }^{5}$ From this description, we can understand why mainstream economics emphasizes that the role of forprofit enterprises is equal to that of firms (see again Johanisova et al., 2013).

${ }^{6}$ For example Eurostat defines a household as housekeeping or social unit that has common arrangements, members share household expenses or daily needs and live in a common residence. Eurostat also provides a definition of collective households (or institutional households), which are for instance hospitals, prisons or military barracks (Eurostat, Online).

${ }^{7}$ Interestingly, the word company, a synonym for firm is linguistically linked to consumption. It comes from the Late Latin word companionem, literally "a bread fellow", meaning "eating bread together'. The association with business and production was not recorded until the $16^{\text {th }}$ century (Online Etymology Dictionary, Online).
} 
same time. However, the market-only understanding fundamentally restricts the essential character of the eco-community economy. The first argument here is that only some of the economic activities performed by eco-communities are related to the market economy regulated by price, while others are embedded in the non-market economy. ${ }^{8}$ Secondly, many of the activities performed by eco-communities that are actually part of the monetized market economy are done so in pursuit of goals other than just economic profit. Therefore price cannot be the only means of allocating resources as is the case with the market mechanism.

\section{Non-market economy: subsistence, gift and exchange in eco-communities}

We will leave the market economy and the narrow economic definitions of households and firms for now, understanding them in the broader sense outlined above, and turn to the part of the eco-community economy that can be described as the non-market economy of community households. From this perspective, eco-communities are composed of one or more household units - depending on whether they occupy one or more dwellings and whether and how members share their income and tasks and household needs ${ }^{9}$.

We shall start with the "three-layer cake with icing" model, constructed by Henderson (1996) using the work of Polanyi (1944) and others, and discussed by Johanisova et al. (2013). Henderson divides the economy into a monetized and non-monetized part. The monetized part comprises all the cash transactions of the private and public sectors (and the illegal sector) of the market economy, while the non-monetized part performs the role of sweat equity or a caring economy. ${ }^{10}$ This part includes all the reciprocal, caring and subsistence activities, such as social services - the care of the elderly, children and the sick; the subsistence economy-household production for personal use and barter exchange;

\footnotetext{
${ }^{8}$ Eco-communities are obviously not the only structures that do not fit the conventional economic categories of households and firms and the logic of the market mechanism. Peasant economics, based on the ideas of Alexander Chayanov for example, discusses the economic performance of subsistence farmers whose goals are not to maximize profits but living conditions. However, as Hammel (2005) points out, the problem with Chayanov's theory is that he considered households to be autarkic units, ignoring the interhousehold exchange of labour and goods, which is at the core of the eco-community economy.

${ }^{9}$ In relation to dwellings: smaller communities often occupy one or two buildings (e.g. Can Tonal, Can Mas Deu or Comunitat Pujarnol in Catalonia), while larger projects create settlements consisting of dozens of houses (e.g. Tamera in Portugal, Friland in Denmark). Typically some of the space is designed to provide common areas. On earnings: in some eco-communities all or part of the individual's income is allocated to a common pool or fund with regular contributions to benefit the whole community; to pay for services or for new investments; to buy goods (e.g. the bulk purchase of food, supplies for households or common areas); or to share the money ultimately-in communes, individuals withdraw money whenever they need it (or up to a certain limit) also for solely individual purposes (e.g. in Can Tonal; Hofkollektif Zwetschke, Austria; Kommune Niederkaufungen in Germany). Big communities are often divided into household units of 15-30 people (called circles in Auroville, India, or bonding groups in Sieben Linden, Germany) which share their income more deeply. Regular costs, such as food and housing are shared among such unit, whereas the community fund is used mainly for infrastructure investments.
}

${ }^{10}$ Henderson (1996) also uses the term love economy. See also Nørgård (2013) who refers to the nonmonetized as the amateur economy. 
do-it-yourself; volunteering; mutual aid and sharing. ${ }^{11}$ Summing up, we can identify three principles in the non-market household economy-gift (mutual aid and sharing), exchange and subsistence. ${ }^{12}$

However, this potentially very large part of economic activity has been neglected by the dominant discourse and is accepted only when it is shifted from the non-monetary to the monetary market economy through processes known as commodification (valuing things and human activities in market prices) and commercialization (entering the market with a new commodity) (see Polanyi, 1944 ${ }^{13}$; also in Johanisova et al., 2013). As a consequence of these processes, the non-monetary economy shrinks, a market price is given to economic activities performed under principles other than for sale for profit, and what remains as non-monetary stays forgotten. Nonetheless there have been attempts to discuss the value of the non-monetary household economy (see e.g. Ironmonger, 1996) and raise awareness particularly from the feminist perspective (for a literature review see D'Alisa \& Cattaneo, 2013, pp. 71-72). This article builds on Polanyi's (1944) claim that the factors of production cannot be commodified; instead the reverse process of decommodification and a new value system must be developed (see e.g. Nierling, 2012; Nørgård, 2013). D'Alisa and Cattaneo (2013) argue in favour of decommodification from a degrowth perspective, stating that household work is less energy demanding than its substitute in the market economy. Instead of monetary criteria, they use time as the value of work.

Collective structures generally support the upscaling of the principles of the nonmarket economy-gift, exchange and subsistence. In eco-communities, relations (including economic relations) among the households are usually tighter and denser and include more varieties of goods and services (and people) than among regular households. Communities are organized to enhance the sharing of infrastructure, space and accessories as well as the performance of collective tasks and the production of goods and services. Following Pickerill (2016), there are non-market economies of scale-the greater capacity of the nonmarket economy reduces the cost of production (e.g. time spent on regular activities such as cooking, shopping and maintenance ${ }^{14}$ ) and eco-community members can obtain more goods

\footnotetext{
${ }^{11}$ Apart from the private (the icing), public and sweat-equity layers, Henderson's (1996) cake includes a Mother Nature base layer which subsidizes the top layers for the environmental costs of production.

${ }^{12}$ Petrapoulou (2013, p. 63) emphasizes that the concepts of exchange (barter economy) and gift (economy of grace) are the building components of the social economy which she sees as being equal to the non-market economy. However, as we will describe in the next section, there is a liminal zone in the social economy between the market and the non-market that needs to be elaborated (more in Johanisova et al., 2013).

${ }^{13}$ In his The Great Transformation Polanyi (1944) gives examples of many traditional economies based on subsistence, mutual aid and redistribution, describing them from a "substantivist position" that is not based on the "formalist" model of neoclassical economics and its maximization of utility and profits. See also Marcel Mauss (2002) who discusses the gift as a form of exchange in traditional societies (originally published in L'Année Sociologique in 1925 as Essai sur le don. Forme et raison de l'échange dans les sociétés archa ques).

${ }^{14}$ However, more research is required on time management in eco-communities. A lot of time may be spent in assemblies and intellectual debates over the collective management, operations, goals or values. It has been said in many eco-communities that the assemblies are unproductive and time-consuming (e.g. in Cooperativa Integral Catalana, under which several of the region's eco-communities presented in this article were established).
} 
and services within the community economy (including house building, expert consultancy as well as cooking, cleaning, food production and education). The non-monetary economy is enhanced (particularly in the daily activities) because its members live together or close enough to each other.

Obviously, the non-monetary economy principles need trellises to function according to the needs of residents (much as price is the logical trellis of the market economy). Therefore, eco-communities develop common values, goals, a collective identity (see Ergas, 2010) and also organizational and decision-making models to ensure that all voices are heard. However, particularly in larger collective structures, listening to everyone's needs and allocating resources accordingly can prove difficult. One strategy is to implement alternative value and exchange systems or local currencies (Dittmer, 2013). HOUR currencies, for example, make it possible to value work time and support mutual aid between members (e.g. at Friland ecovillage in Denmark), while convertible local currencies can facilitate the exchange of goods and services. When they are open to non-residents, these systems also enhance exchange in the local economy. With the number of local currencies having grown in recent years, it is also possible for smaller eco-communities to join these systems. For example a system of convertible local currencies in Catalonia, managed by the umbrella organization Cooperativa Integral Catalana, has become popular among many small and medium ecocommunities (e.g. Can Tonal, Som Pujarnol or Calafou). Similarly LETS systems (Local Exchange Trade Systems) enable exchange between members as well as in the local economy (e.g. the Dolphin Community in Germany).

Finally, it has to be remembered that the right mix of gift, exchange and subsistence principles differs substantially between eco-communities. In reality, some eco-communities focus on individual subsistence in food or energy and exchange the surplus, whereas others manage the land as commons, and some focus particularly on mutual aid (e.g. building houses, caring for children) or on sharing common equipment and infrastructure. ${ }^{15}$

\section{Liminal zone of production: the not-only-for-profit eco-community economy}

When transitioning towards a sustainable post-carbon future, eco-communities have to be financially sustainable. Strategies for financial sustainability obviously differ depending on the socio-economic situation, political goals, environmental values and the magnitude of the non-market economy of community households. Nevertheless, every community has to generate enough financial resources to 1) develop settlements in the initial phase, 2) invest in new development, 3) maintain regular operations within the current infrastructure and 4) finance the personal needs of individuals over and above those met within the non-market community household economy.

\footnotetext{
${ }^{15}$ The mutual aid and sharing particularly manifest in cohousing structures. The residents benefit from a typical rotating system of community tasks (e.g. cooking, cleaning, shopping) so that for example members of Trudeslund cohousing in Denmark have to cook only once in approx. every five weeks. Cohousing members often share kitchen supplies, washing machines, cars, run kindergartens and other mutual social services.
} 
We have already discussed the fact that some of the financing comes from renting the factors of production in the market. Individuals work for private companies or in the public sector or provide professional services and consultancies (see e.g. Gálová, 2013, a study of Zaježka, a Slovak ecovillage). Some communities rent land or offices to entities and individuals outside the community (Lietaert, 2010). In this section, we will look at activities that are consistent with the community vision, integrated within the organizational structure, developed to serve the local economy and for the benefit of the eco-community or its members. Coming back to the second argument that criticizes the application of the two-sector model to eco-community structures, we could say that these activities are part of the not-only-for-profit economy of community firms. As Johanisova et al. (2013) point out, not-only-for-profit activities (together with not-for-profit ${ }^{16}$ ) form a liminal zone between the monetized and non-monetized parts of the economy as explored in Henderson (1996) and sometimes described as the "social economy" or "third sector" (see e.g. Birkhölzer, 2006). We will build on the conceptual work of Johanisova et al. (2013) and use their definitions of primary and secondary social enterprises to understand the different levels in the economy of community firms.

The term primary social enterprises can be used to describe activities that produce goods and services to serve outside (preferably nearby) communities, that have explicit social or environmental goals, that are at least partially attached to the market and that generate resources (not necessarily financial) that benefit the eco-community. In ecocommunities, these usually take the form of food production and manufacturing, social services, consultancies, (environmental) education or cultural events for example. While some activities partly serve the local community and partly the eco-community (e.g. food production) and therefore link substantially with the non-market economy, other activities focus on the outside economy solely. Small eco-communities often concentrate on a few activities that are developed centrally and are under the (economic) control of the community body; big ones can create dozens of enterprises that, depending on the organization, are also controlled by the community body or perform autonomously. Some enterprises may be run by individuals in order to meet their personal financial needs, while some are run by a group of residents and some are organized by the whole community. ${ }^{17}$ The liminality of the primary social enterprises can be seen in the fact that they have other than solely for-profit

\footnotetext{
${ }^{16}$ Understanding eco-communities as complex economic micro-systems, we subsume the not-for-profit into the not-only-for-profit.

${ }^{17}$ An example of the first one mentioned, an eco-community with a strong community enterprise, is Lakabe in the Basque country, Spain. In the 1980s the community, like others in the region, occupied an abandoned village in the mountains to live off-grid. Currently, it operates a locally based bakery which supports the villagers financially. Similarly, Can Tonal operates a micro-brewery business, while Crystal Waters community in Australia runs a consultant company called Ecological Solutions.

An example of a multi-enterprise community is Earthaven, USA. The enterprises in Earthaven were developed to finance the residents and enable them to work on-site (Dawson et al., 2010). In Calafou project, Catalonia, the members are required to run their personal enterprises using preferably the social currency system to work on-site and not in the capitalist system. Similarly Auroville, Findhorn Foundation and EcoVillage Ithaca run many enterprises, often organized as co-ops, either linked to the community body or performing autonomously.
} 
goals and often have two types of customers-market (outside) and non-market (inner) ones. The economic micro-system of a complex eco-community may contain examples of all these enterprises-some operate to support financial sustainability, while others focus more on different aspects (social, ecological, political, etc.).

Building on the work of Bruyn (1992), Johanisova et al. (2013, p. 14) defines structures that provide secondary business services and non-market capital (land, natural resources, manufactured capital, financial capital and knowledge/skills) to primary social enterprises as secondary social enterprises. According to Bruyn (1992) the non-market capital is "taken out of the market and placed under democratic control". This means that it is provided at a subsidized cost that takes into account the social and environmental benefits of production (positive externalities in economic terms) and that it is owned by a democratic body composed of representatives of the primary social enterprises.

Applying the concept to eco-communities, it becomes clear that primary social enterprises are supported by the community organizational body (the secondary social enterprise) in several ways. One service provided by the secondary enterprise could be the local currency system discussed in the last section. Others could include the community banks that provide loans with zero interest rates to establish primary social enterprises in bigger communities (Dawson, 2004). There is also the work of volunteers ${ }^{18}$, cheaper rents for land and housing, knowledge and skills and the sharing of infrastructure between households and firms, which can all be seen as services provided by the community. Finally, the role of eco-communities as secondary social enterprises can be seen in the provision of services and non-market capital to other individuals and enterprises in the local area, for example supporting the development of microbusinesses (e.g. in Vale da Lama, where a broader collective connected with the project can develop small enterprises using the project infrastructure) or providing land and infrastructure to local farmers (e.g. in EcoVillage Ithaca, where the community land is rented out to locals, see Dawson, 2010). In many educational projects, the eco-community is established to run an enterprise which then becomes the primary driver of activities (e.g. in Vale da Lama or Makvärket Cultural and the Environmental Collective, Denmark). In these situations, the eco-community as a whole can be seen as a secondary social enterprise. ${ }^{19}$

\section{Suggestions for further research}

Eco-communities are often understood as housing alternatives which experiment with ecological building and farming, whilst also experimenting socially. This article aimed to discuss the economic dimension, defining eco-communities as economic micro-systems

\footnotetext{
${ }^{18}$ In some eco-communities volunteers come to help individual members, (e.g. in Friland). Others run volunteer programmes in which volunteers help with the maintenance and building of the community infrastructure and with the production of the primary enterprise's goods and services (e.g. Vale da Lama in Portugal).

${ }^{19}$ In Vale da Lama for example, the residency function supports the enterprise by saving not only resources through the sharing of infrastructure but it also enables the workers (the residents of ecocommunity) to be paid lower wages, since they are not obliged to pay rent and fresh food is available for them from the farm run by the enterprise.
} 
capable of producing goods and services to meet the needs of members directly through nonmarket activities and also indirectly through the activities of the local economy.

We understand that the non-market and not-only-for-profit activities are usually conducted in accordance with common values or a code of conduct. However, their roles in the eco-community economy may differ substantially. Whereas some eco-communities are organized to enhance the non-market household economy and the residents work autonomously from the community in the outside economy, others are concerned with the on-site employment of the residents and even develop collective enterprises which serve the eco-community and/or outside economy. Some eco-communities are established with the primary goal of running a collective enterprise and not the creation of its members' livelihoods. The complexity of economic micro-systems established in eco-communities can be seen in bigger projects, where many of the examples run simultaneously. However, some of the smaller projects (e.g. in Catalonia) are well-networked within their regions and local economies to take advantage of the secondary social enterprises.

The eco-community economy creates synergies between the two types of activities-ecoresidents are capable of the non-market production of goods and services and create trellises to support the development of collective or individual not-only-for-profit activities. Since these trellises are also taken out of the market (we used the concept of non-market capital), they can subsidize (e.g. using economies of scale, cost reduction, risk reduction, knowledge) activities left in the competitive market.

Obviously, there are several constraints that the eco-residents have to deal with. In relation to this article, the question arises as to how to balance the non-market and not-onlyfor-profit, as well as the for-profit (earning money elsewhere) activities. This issue is of particular relevance during the initial phases of community development, with the high cost of land, housing and infrastructure. Following Boyer (2014), Dawson (2010), or Johanisova et al. (2013) we might assume that there is a need to create local partnerships and find and establish secondary social enterprises in the local area that could support new developments but also support the transition process of existing projects.

Further research is needed to explore the role of activities in the economic micro-systems of eco-communities and particularly how they influence the primary ecological and social goals and how they are economically (and financially) viable and sustainable.

\section{References}

Benkler, Y., \& Nissenbaum, H. (2006). Commons-based peer production and virtue. Journal of Political Philosophy, 14(4), 394-419.

Birkhölzer, K. (2006). Development and perspectives of the social economy or third sector in Germany (pp. 1-19). Presented at the "Concepts of the Third Sector: The European Debate", organized by the EMES-Network and the International Society for Third Sector Research / ISTR, 27-29 April 2005 in Paris, France, Berlin: Technologie-Netzwerk Berlin e.V.

Borgaza, C., \& Defourny, J. (Eds.). (2001). The emergence of social enterprise (1st ed.). London: Routledge.

Boyer, R. (2014). Sociotechnical transitions and urban planning: A case study of eco-cohousing in Tompkins County, New York. Journal of Planning Education and Research. 
Bruyn, S. (1992). A new direction for community development in the United States. In P. Ekins \& M. Max-Neef (Eds.), Real-life economics: Understanding wealth creation (pp. 372-381). London: Routledge.

Cattaneo, C., \& Gavaldà, M. (2010). The experience of rurban squats in Collserola, Barcelona: What kind of degrowth? Journal of Cleaner Production, 18(6), 581-589.

Celata, F., \& Sanna, V. S. (2014). Community activism and sustainability: A multi-dimensional assessment (Working Paper MEMOTEF No. 137) (p. 48). Rome: University of Rome La Sapienza. Retrieved from: http://www.memotef.uniroma1.it/sites/dipartimento/files/wpapers/documenti/ FullTextWP137.pdf

Chatterton, P. (2013). Towards an agenda for post-carbon cities: Lessons from Lilac, the UK's First Ecological, Affordable Cohousing Community. International Journal of Urban and Regional Research, 37(5), 1654-1674.

Christian, D. L. (2007). Finding community. How to join an ecovillage or intentional community. Canada: New Society Publishers.

Connors, P., \& McDonald, P. (2011). Transitioning communities: Community, participation and the transition town movement. Community Development Journal, 46(4), 558-572.

D'Alisa, G., \& Cattaneo, C. (2013). Household work and energy consumption: A degrowth perspective. Catalonia's case study. Journal of Cleaner Production, 38, 71-79.

Dawson, J. (2004). A tale of two ecovillages reviving the health of local communities. Resurgence Magazine (No. 227).

Dawson, J. (2010). Ecovillages. New frontiers for sustainability (Reprinted). Dartington, Totnes: Green Books Ltd.

Dawson, J., Jackson, J. T. R., \& Norberg-Hodge, H. (2010). Gaian economics: Living well within planetary limits. East Meon: Permament Publications.

DePasqualin, L., Haid, M., Krainz, L., \& Mandl, B. (2008). Arbeitsgruppe 2: Systemodell "Ökoforf”. In Nachhältige Veränderungsprozesse in Regionen. Berichte aus den Umweltsystemwissenschaften (pp. 50-85). Karl-Franzens-Universitat Graz.

Dittmer, K. (2013). Local currencies for purposive degrowth? A quality check of some proposals for changing money-as-usual. Journal of Cleaner Production, 54, 3-13.

Ergas, C. (2010). A model of sustainable living: Collective identity in an urban ecovillage. Organization \& Environment, 23(1), 32-54.

Fuchs, K., \& Tuleja, P. (2005). Základy ekonomie (2nd ed.). [The basic of economics]. Praha: Ekopress.

Gálová, A. (2013). Jak se uživit na ekovesnici? Př́padová studie ekovesnice Zaježka na Slovensku [How to make a living in an ecovillage? Case study of the ecovillage Zaježka in Slovakia]. (Diploma thesis). Brno: Masarykova univerzita.

Hammel, E. A. (2005). Chayanov revisited: A model for the economics of complex kin units. Proceedings of the National Academy of Sciences, 102(19), 7043-7046.

Hawasly, M., Corne, D., \& Roaf, S. (2010). Social networks save energy: Optimizing energy consumption in an ecovillage via agent-based simulation. Architectural Science Review, 53(1), 126-140.

Henderson, H. (1996). Building a win-win world. Life beyond global economic welfare (1st ed.). San Francisco: Berrett-Koehler Publishers.

Hopkins, R. J. (2010). Localisation and resilience at the local level: The case of Transition Town Totnes (Devon, UK) (Doctoral thesis). University of Plymouth.

Ironmonger, D. (1996). Counting outputs, capital inputs and caring labor: Estimating gross household product. Feminist Economics, 2(3), 37-64.

Jackson, H. (Ed.). (1999). Creating harmony. Hampshire, England: Gaia Trust, Permanent Publications. 
Jackson, J. T. R. (2000). And we are doing it! Building an ecovillage future. San Francisco: Robert D. Reed Publishers.

Johanisova, N., Crabtree, T., \& Fraňková, E. (2013). Social enterprises and non-market capitals: A path to degrowth? Journal of Cleaner Production, 38, 7-16.

Johanisová, N., \& Fraňková, E. (2013). Eco-social enterprises in practice and theory - A radical versus mainstream view. In M. Anastasiadis (Ed.), ECO-WISE - Social Enterprises as Sustainable Actors. Concepts, Performances, Impacts. Brenen: Europäischer Hochschulverlag.

Jones, O. (2011). Keeping it together: A comparative analysis of four long-established intentional communities in New Zealand. (Doctor of Philosophy (PhD) Thesis). Hamilton, New Zealand: University of Waikato.

Kirby, A. (2003). Redefining social and environmental relations at the ecovillage at Ithaca: A case study. Journal of Environmental Psychology, 23(3), 323-332.

Lietaert, M. (2010). Cohousing's relevance to degrowth theories. Journal of Cleaner Production, 18(6), 576-580.

Litfin, K. T. (2014). Ecovillages: Lessons for sustainable community. Cambridge: Polity Press.

Lockyer, J. (2007). Sustainability and utopianism. An ethnography of cultural critique in contemporary intentional communities. (Dissertation). Athens / Georgia: The University of Georgia.

Mauss, M. (2002). The Gift. The form and reason for exchange in archaic societies. London: Routledge.

Meijering, L. (2006). Making a place of their own: Rural intentional communities in Northwest Europe. (Doctoral dissertation). Groningen: Faculty of Spatial Sciences, University of Groningen.

Meltzer, G. (2010). Ecovillages and cohousing: A personal take on their similarities and differences. In D. U. Vestbro (Ed.), Living together - Cohousing ideas and realities around the world (pp. 105-113). Stockholm: Division of Urban and Regional Studies, Royal Institute of Technology in collaboration with Kollektivhus NU. Retrieved from: http://www.academia.edu/1801032/ Ecovillages_and_Cohousing_A_personal_take_on_their_similarities_and_differences

Metcalf, B. (2012). Utopian struggle: Preconceptions and realities of intentional communities. In M. Andreas \& F. Wagner (Eds.), Realizing utopia: Ecovillage endeavors and academic approaches (pp. 21-29).

Mulder, K., Costanza, R., \& Erickson, J. (2006). The contribution of built, human, social and natural capital to quality of life in intentional and unintentional communities. Ecological Economics, 59(1), 13-23.

Newman, L., \& Nixon, D. (2014). Farming in an agriburban ecovillage development: An approach to limiting agricultural/residential conflict. SAGE Open, October-December, 2014, 1-10.

Nierling, L. (2012). "This is a bit of the good life": Recognition of unpaid work from the perspective of degrowth. Ecological Economics, 84, 240-246.

Nørgård, J. S. (2013). Happy degrowth through more amateur economy. Journal of Cleaner Production, $38,61-70$.

Petrapoulou, C. (2013). "Alternative Networks of Collectivities" and "Solidarity-Cooperative Economy" in Greek cities: Exploring their theoretical origins. Journal of Regional Socio-Economic Issues, $3(2), 61-86$.

Pickerill, J. (2016). Building the commons in eco-communities. In S. Kirwan, L. Dawney, \& J. Brigstocke (Eds.), Space, power and the commons: The struggle for alternative futures. London: Routledge.

Pickerill, J., \& Maxey, L. (2012). Low impact development: Radical housing solutions from the grassroots. In A. Davies (Ed.), Enterprising communities: Grassroots sustainability innovations (Advances in Ecopolitics, Volume 9, pp.65-83). Emerald Group Publishing Limited.

Polanyi, K. (1944). The great transformation: The political and economic origins of our time. Mattituck, New York: Amereon house. 
Samuelson, P. A., \& Nordhaus, W. D. (1992). Economics (14th ed.). New York: McGraw-Hill.

Sanguinetti, A. (2014). Transformational practices in cohousing: Enhancing residents' connection to community and nature. Journal of Environmental Psychology, 40, 86-96.

Sargisson, L. (2007). Strange places: Estrangement, utopianism, and intentional communities. Utopian Studies, 18(3), 393-424.

Seyfang, G. (2010). Community action for sustainable housing: Building a low-carbon future. Energy Policy, 38(12), 7624-7633.

Seyfang, G., \& Smith, A. (2007). Grassroots innovations for sustainable development: Towards a new research and policy agenda. Environmental Politics, 16(4), 584-603.

Simon, K.-H., Matovelle, A., Fuhr, D., Kilmer-Kirsch, K.-P., \& Dangelmeyer, P. (2004). Zusammenfassender Endbericht zum Vorhaben "Gemeinschaftliche Lebens- und Wirtschaftsweisen und ihre Umweltrelevanz" (pp. 31). Kassel: Universität Kassel.

Tinsley, S., \& George, H. (2006). Ecological footprint of the Findhorn Foundation and Community. Moray: Sustainable Development Research Centre.

Wagner, F. (2012). Ecovillage research review. In Realizing utopia: Ecovillage endeavors and academic approaches (pp. 81-94). Munich: Rachel Carson Center for Environment and Society.

Walker, L. (2005). EcoVillage at Ithaca: Pioneering a sustainable culture. Gabriola, BC: New Society Publishers.

Williams, J. (2008). Predicting an American future for cohousing. Futures, 40(3), 268-286.

Xue, J. (2014). Is eco-village/urban village the future of a degrowth society? An urban planner's perspective. Ecological Economics, 105, 130-138.

Zhu, D., Kung, M., Whiteford, B., \& Boswell-Ebersole, A. (2012). Analysis of sustainable materials used in ecovillages: Review of progress in BedZED and Masdar city. Journal of Wuhan University of Technology-Mater. Sci. Ed., 27(5), 1004-1007.

Webpages:

Affordable concept. Lilac: Low Impact Living Affordable Community, Online http://lilac.coop/concept/ affordable.html, accessed $20^{\text {th }}$ June 2016

Cooperativa Integral Catalana, Online http://cooperativa.cat/, accessed 20 June 2016

Glossary:Household - social statistics, Eurostat, Online http://ec.europa.eu/eurostat/statisticsexplained/index.php/Glossary:Household_-_social_statistics, accessed 20 $0^{\text {th }}$ June 2016

Online Etymology Dictionary, Online http://www.etymonline.com/index.php?term=company, accessed $20^{\text {th }}$ June 2016

Department of Environmental Studies,

Masaryk University

60200 Brno,

Joštova 10 ,

Czech Republic

E-mail: jan.blazek86@gmail.com 